\title{
EDMODO IN THE CLASS: THE USE OF ONLINE LEARNING IN THE CLASS SEEN FROM STUDENTS' VOICE
}

\author{
Mahendra Puji Permana Aji ${ }^{1}$, Suhartono ${ }^{2}$ \\ ${ }^{1}$ Nusantara PGRI Kediri University, Indonesia \\ 1inbox@mahendrapuji.web.id, \\ ${ }^{2}$ Nusantara PGRI Kediri University, Indonesia \\ ${ }^{2}$ nurmantono@yahoo.com
}

\begin{abstract}
Online learning has been main concern in today's teaching learning process since the rising use of internet. It offers many variant activities and it becomes new alternative way to communicate among teacher and students. Recently students and teachers are expected to have decent knowledge in digital learning as one way to facilitate their learning process. One form of digital learning is using Edmodo in the class. The e-learning model using edmodo was developed to support teaching and learning process in University of Nusantara PGRI Kediri. This media offers an authentic material that can be accessed anytime and anywhere. This model also gives the external links to get the other resources in the World Wide Web. The external links given is related to a discussion topic or material, and it is to improve the students' knowledge and skill in teaching and learning. Because this media is a e-learning model, the students enjoy when they browse and take a look into the material provided. Some of researchers have done the research on it, yet these studies mostly focus on the teachers' perception towards its application in their classes. This study is a bit different as it is concentrated on students' perceptions or voice towards Edmodo application in the class. The aim of this study is to explore students' perception or students' voice on online learning particularly Edmodo application in class.
\end{abstract}

Keywords: Edmodo, online learning, students' voice.

\section{INTRODUCTION}

Improving the quality of education is absolutely necessary in order to improve the welfare of the nation. An effort to improve the quality of education is constantly being done in various ways and at various educational components. Trainings educators continually held to provide insight and knowledge about the learning strategy deemed appropriate for each topic of learning and each level of education. To realize the functions and achieve educational goals, improving quality of learning in the classroom is one thing that is important.

However, everything is useless because there is no one can develop the suitable method for teaching and learning. There has been problem in teaching and learning English for years, a large number of students in the class and limited time allocated to teach English is the one that contribute to the outgoing problem in teaching English. Forty students in a one class is a serious problem for teacher in Nusantara PGRI Kediri University, students never get big opportunities to improve their ability. A hundred minutes given for each meeting and one-time meeting on a week is not long enough for them to improve their skill and knowledge.

The big number of students in each class and teachers with low mastery of English are two obvious factors that contribute to the ongoing problems in ELT (Asabere NY., \&Brew E, 2012). Other reasons support that statement are: (1) limited time allocated for teaching and learning in the class, (2) students have limited time to comprehend the materials in the class because the teacher is more concerned with finishing the topic, (3) there are lack of good and authentic 
materials to support teaching learning process, and (4) no English social community outside the classroom.

In the traditional teaching methods in which students are usually passively spoon fed with large number of grammatical rules and vocabulary, teacher has a full control to the student, but Edmodo 2.3 has shown its with different taste. Students can expose to sound, video, and animation of the authentic target language, which can give the students the strong visual impact and make them get involved in the authentic language environment more completely.

Learners' language acquisition can be improved by means of using the computer's integration of text, sound, graphics and image to present the learning content. When the computer is connected to the web, the internet offers a lot of opportunities for students to interact with native speakers in a convenient way and provides access to the most updated information throughout the world. Also, teachers can present video and audio materials separately or simultaneously to the students according to the teacher's objectives. In this case, not only could the Edmodo 2.3 make the students get more interested in English learning, but also more progress could be made than in the traditional classroom. Nowadays, most of school in this country has their own computer laboratory, connecting with World Wide Web and many school using them for learning process.

Teachers should provide course material with different packages to attract the students. Adding the video, building a chat room, make a forum discussion, so students can interact and share their idea not only in the class but they can do it everywhere, anywhere they want to do it. The important point is, students can get the different experience in teaching and learning process. Barolli et al. (2006) confirm that web-based e-learning system increases study efficiency when there is enough stimulating motivation given to the learners. It indicates that external links to other related websites give students exposure of authentic used of English. One of the benefits of e-learning learning is the availability of links to other sites which provide similar information, exercise, explanation, simulation or task.

Students need a media to improve their English skill out of class. LMS Edmodo 2.3 gives the opportunity for student to increase their resources and material out of class. Teacher who have uploaded the material and resources on the edmodo library ask the students to access "virtual class" out of class session, so the media will be a supplement for students to improve their ability and they will get the material outside the class. Students need an additional material and resources to access after the teaching and learning process, anytime what they want to access.

With the development of technology, multimedia and e-learning teaching is increasingly accepted as a means of English language instruction. This study attempts to design a e-learning model for teaching media using Edmodo 2.3 for teaching and learning in Nusantara PGRI Kediri University. This model uses Learning Management System (LMS) platform called Edmodo 2.3 which has appropriate feature to use Information Communication Technology in teaching learning process. The LMS not only provided the text material, it also provided multimedia platform material like mp3, video, animation, or external links to the other website and resources, it will be a good learning media to support teaching and learning process.

Regarding to the study, Edmodo is utilized in blended learning mode normally the meeting for the course is 16 meetings and it blended within online and offline meeting. Online meeting using Edmodo mostly concentrates on providing various materials such as using you tube, e-book, e-story and some article taken from 
internet. Also, the assignments were delivered using this mode. Offline meeting was done to make students get more comprehension on the material given via Edmodo.

\section{LITERATURE REVIEW}

2.1 Strength of e-learning

Rubin (1987) suggested that the use of video has been found to effectively develop skills and grammar. Johnstone and Milne (1995) stated that the use of a teacher-controlled multimedia tool increased the amount of communicative discourse in the classroom by both teachers and students. Students will become more active and autonomous in multimedia environment. The attractive pictures, animation or sound will be engaged in the language learning effectively for them. They will collaborate with their classmates to solve a problem or complete a project in a relaxing environment. Students can learn on their own according to their plans or purposes and teachers can act more as a guide rather than a knowledge-giver. This environment increases the effectiveness of language learning and teaching.

\subsection{LMS Edmodo}

Based on Kongchan in Purnawarman, Pupung, Susilawati, Sudayana (2012), Edmodo is a form of technological development for educational purposes, is believed to be of assistance for teachers in language classrooms. Edmodo is designed very modestly, almost similar to Facebook, and provides space for teachers, students, and even parents to maximize teaching and learning process.

According to Cauley in Shams-Abadidkk. (2015) stated that Edmodo is an educational website that takes the ideas of a social network and refines them and makes it appropriate for a classroom. Using Edmodo, students and teachers can reach out to one another and connect by sharing ideas, problems, and helpful tips. It means by using Edmodo, both teacher and student can engage activity that support language learning and they can stay connect each other through sharing ideas, problems, and helpful tips. In addition, Edmodo is school based social network environment (Raka in Imam, 2013) so like other social media such as facebook, twitter, path and others, Edmodo also used to facilitate communication among teacher, student, and parent in school environment. In order to keep student from any distraction when using Edmodo, the content of Edmodo is controlled by teacher. In this way teacher can prevent inappropriate things as in public social media.

\section{METHODS}

The researcher used triangulation approach in gathering data of the research. Survey questionnaire was used as the main research instrument of the research. Moreover, the researcher also conducted interview to some participants and researched related literature about the current research.

This research was based on the data taken in 2017 from English education department students of University of Nusantara PGRI Kediri who registered in IT for Language Teaching course. This study applied descriptive study which aims to explore students' voice on Edmodo application in the class of IT for Language Teaching. Some researches on Edmodo application have been done previously but this study is a bit different. It investigates on students' insight on this online learning mode.

The population of the research was the sixth semester students of English Education study program which consists of two classes. Class A consists of 28 
students, class B consists of 34 students and class $\mathrm{C}$ consists of 32 students. For the sampling, the researcher used purposive sampling and took class $\mathrm{C}$ as the respondent with 32 students in it.

In collecting the data, the respondents were given open-ended questionnaires to reveal their insight toward Edmodo usage in the class. The questionnaires were given at the end the class of IT for Language Teaching course. These open-ended questionnaires focus on the strength, the weakness, the students' opinion and the suggestion toward Edmodo application.

\section{FINDINGS AND DISCUSSION}

This part covers the result of the open-ended questionnaire distributed to the students who registered in IT for Language Teaching course. The findings will discuss about student opinion Edmodo usage with blended learning mode in IT for Language Teaching course, the strength, the weaknesses and the students' suggestion on virtual learning environments and social networking sites within educational settings.

\subsection{Students' Opinion on Edmodo Application}

From the questionnaire given to the students, the first question focuses on students' opinion about the application of Edmodo. Almost all students in that class strongly agreed or agreed that online activities in Edmodo provide them with new environment and interesting media for learning.

They enjoy using it as new thing in their way of learning process. In students' opinion, the word useful, easy, no need to meet face to face, flexible, discipline, and skillful dominates their answer in the first question. Using Edmodo with blended learning mode in IT for Language Teaching course put students in positive condition. Online learning with Edmodo as the bridge media system help the students to have various materials for learning. They can join the online class, participate the discussion in Edmodo by giving comment, feedback and solution. Based on the data there were 4 students said that blended learning makes them flexible in learning. They can learn anywhere and anytime they want without class or note book.

In IT for Language Teaching class, Edmodo is used to provide many materials to improve their skill. The materials presented were from YouTube (video tutorial), Audio file; e-book.

They stated that it is easy to learn and useful for them. There were 13 students agreed that Edmodo easy and useful to learn as they can access it outside class, then 9 students said that they do not need to meet teacher to ask the unclear things as Edmodo the answers. In line with student's statement, Cauley (2013) stated that this kind of learning tool make students easy to learn as it is a kind of additional learning resources that be accessed outside the classroom.

Another opinion of students reveal that Edmodo supports them discipline and skillful toward the technology. There were 5 voices of the students stated that the assignments given in Edmodo trained them to be more discipline because there is a time limit their assignment. In addition, there was 1 students felt that Edmodo make him more skillful in accessing this learning technology. The data result from students' opinion on Edmodo showed that 6 students said flexible, 13 students said easy to access, 9 students said no need to meet face to face, 6 students said edmodo is flexible, 3 student said discipline and 1 student said skillful. 


\subsection{The Strength of Edmodo}

The second questionnaire focuses on students' voice about the strength of Edmodo, the data show some words usage in students' answer toward are easy to use, flexible, more independent, responsibility and objective. There were 5 students stated that Edmodo made them flexible in learning as they have more time to learn and comprehend the material outside class and all material can be accessed anywhere and anytime through their laptop or smart phone. The students also said that this application is easy to learn. These 8 students gave the same opinion on it as they feel easy and quick to learn and access the application.

Another opinion revealed on Edmodo usage that 3 students felt being more independent to learn when they start using Edmodo. They have to access the application by themselves and learn the material through Edmodo as well as do the assignment given alone. They cannot depend on others to do the assignment. Similar opinion was also stated by 3 students that besides being more independent, Edmodo made them have big responsibility in learning and finishing their assignment on time based on due date set by the teacher. Moreover, 8 students said that using Edmodo gave them much more time to finish the assignment. The time allotted to do assignment given by the researcher was three up to four days. Therefore, the students still have more flexible time to finish their assignment out side the class.

\subsection{The Weakness of Edmodo}

The third question in the questionnaire was to find out the weakness of Edmodo usage in the class. Students' responses on the question varied by using the word copy, accessibility, least exploration, account and least understanding. From 32 students in the class, there were 2 students agreed saying that the weakness of Edmodo was easy to copy another students' work. In fact, this thing happened because some students put their task or assignment in the main menu even though they have been told put their work in the "assignment Centre menu to avoid plagiarism.

The highest response on the question was about the accessibility on Edmodo. There were 5 students complained on the way they access the application. The limited account of their internet quota put them in a small problem on accessing the material and the assignment given. Another problem faced by the students was the exploration toward Edmodo. There were 6 students criticized the least exploration on the application because the limit of internet quota they have. Interestingly, from the data show there were 3 students said that face to face meeting in the class better than online meeting.

\subsection{Students' suggestion on Edmodo}

Students' voice on the last question was about their suggestion about the application of Edmodo in the class. The suggestion given by student was not expressed by the whole members of the class. From 32 students, only 10 students gave their response on the last question while others did not answer the question. The first suggestion was said by only 3 students that Edmodo can help them to share knowledge on technology. Other suggestion from 3 students was about the interesting feature Edmodo has. He enjoyed exploring Edmodo feature in learning. Then 8 students also gave some suggestion on having more training in exploring this Edmodo especially some important menu like attach file or working with assignment, while 4 students explained to have extra email account if they failed registration at the first time. Other suggestion was offered by 4 students that 
Edmodo application should be used in other courses as it has many benefits in learning,

\section{CONCLUSION}

Based on these results, majority of participants strongly agreed and agreed that Edmodo is indeed a great platform as a tool for learning because of its features and benefits such as active participation in online class activities. Edmodo application in class help much the students in having more knowledge on technology using online learning mode. They reported that learning through Edmodo gave them flexible and more much time to learn not only in the class but also outside the class. Also, it is easy to use features in submitting online tasks, easy to access reference materials and increase of student motivation because of online activities and discussions.

However, a problem encountered by the student when they want to access edmodo is internet access, not all students have internet access. In addition, teacher should make preparation in order Edmodo can give positive effect to class.

\section{REFERENCES}

Asabere, Nana Y and Mends-Brew, Edwin. 2012 Distance Learning and Electronic Learning (E-Learning). Esjournal. Volume 2 No 9, September 2012

Barolli, Leonard \& Akio Koyama. (Eds).2006. A web-based e-learning system for increasing study efficiency by stimulating learner's motivation. Japan: Spring Science+Business Media

Dewi, Finita. (2014) EDMODO: A Social Learning Platform for Blended Learning Class in Higher Education. Retrieved from www.academia.edu,March 28, 2016

Gillani, Bijan. 2005. Cognitive Theory and The Design Of Education To Work Connection. Valencia, Spain: INNODOCT, May 08-09, 2014

J. Johnstone and L. Milne, 1995. "Scaffolding second language communicative discourse with teacher-controlled multimedia," Foreign Language Annal, 28, 315-329.

R. E. Mayer, J. L. Plass, D. M. Chun and D. Leutner, 1998. "Supporting visual and verbal learning preferencesin a second-language multimedia learning environment, " Journal of Educational Psychology, 90, 25-36.

Smith, P. L., \& Ragan, T. J. 2005. Instructional Design (Third ed.).Hoboken, NJ: John Wiley\&Sons, Inc.

Warschauer, Mark \& Deborah Healey. (Eds).1998.Computers and language learning: an overview. United Kingdom: Cambridge University Press 